Сас Л.С.

\title{
ІННОВАЦІЙНИЙ МЕНЕДЖМЕНТ У ПРОЦЕСІ ТЕХНОЛОГІЧНОГО ОНОВЛЕННЯ ВИРОБНИЦТВА СІЛЬСЬКОГОСПОДАРСЬКИХ ПІДПРИЕМСТВ
}

\begin{abstract}
У статті обгрунтовано важливість та необхідність управління прочесом інноваційного розвитку сільськогосподарських підприємств, зокрема технологічним оновленням виробництва. Розкрито сутність інноваційного менеджменту. Висвітлено завдання інноваційного менеджменту щодо технологічного оновлення виробництва сільськогосподарських підприємств. Визначено та розглянуто функиіі інноваційного менеджменту в процесі технологічного оновлення виробництва, зокрема: планування, мотивацію, організацію, керівництво, контроль, розвиток.
\end{abstract}

Ключові слова: інноваційний менеджмент, технологічне оновлення виробництва, сільськогосподарське підприємство, завдання, функиії.

Постановка проблеми. Одним із напрямів, які забезпечують результативне функціонування сільськогосподарських підприємств на ринку, $є$ активна інноваційна діяльність. Однак інноваційний шлях розвитку здатний забезпечити ефективну роботу суб'єктів господарювання тільки за умови належного управління цим процесом на підприємстві, визначення стратегії і тактики його здійснення. При цьому інноваційним процесом вважається процес розробки, виготовлення i просування інновації на ринок $[1$, с.265], який включає бізнес-план, технічне завдання, опис технологічних процесів та ін. [2, с.623].

Погоджуємось 3 С.М. Ілляшенко, який під інноваційним розвитком суб'єкта господарської діяльності розуміє розвиток, що спирається на постійний пошук і використання нових способів i сфер реалізації свого потенціалу в умовах змін зовнішнього середовища в рамках його місії і вибраної мотивації діяльності та пов'язаний 3 модифікацією існуючих i формуванням нових ринків збуту, а завданням механізму управління інноваційним розвитком вважає орієнтацію діяльності на безупинний пошук і реалізацію ринкових можливостей інноваційного розвитку [3, c. 27].

Інноваційний шлях розвитку сільськогосподарського підприємства передбачає періодичне технологічне оновлення виробництва, що $\epsilon$ запорукою його ефективного функціонування. Так, технологічна складова, на думку О.І. Волкова, М.П. Денисенко, А.П. Гречан [1, с. 279 ; 284-286], є однією із складових, за якою оцінюється інноваційний потенціал

(C) Сас Людмила Степанівна, к.е.н., доцент, доцент кафедри обліку i аудиту, ДВНЗ «Прикарпатський національний університет імені Василя Стефаника», м. Івано-Франківськ, email: sas_lyudmyla@ukr.net підприємства, поряд 3 ринковою, інтелектуальною, кадровою, інформаційною, інтерфейсною та науково-дослідною.

Аналіз останніх досліджень і публікацій. Проблематика інноваційного розвитку підприємств та інноваційного менеджменту є об'єктом дослідження багатьох вчених, зокрема: О.І. Вікарчук, А.В. Вісільової, О.І. Волкова, В.Г. Герасимчук, А.П. Гречана, М.П. Денисенко, В. В. Зянько, С.М. Ілляшенко, С.В. Князя, А.Е. Розенплентера, О.А. Колесникова, Ю.М. Уткіної. Н.М. Комарницької, Однак питання менеджменту інноваційного розвитку в контексті технологічного оновлення виробництва сільськогосподарських підприємств залишається мало вивченим.

Формулювання цілей статті. Метою статті $\epsilon$ 3'ясування ролі інноваційного менеджменту у процесі технологічного оновлення виробництва сільськогосподарських підприємств, визначення його завдань та функцій.

Опис основного матеріалу дослідження. Сільськогосподарське підприємство є системою, що охоплює безліч складових, які безупинно взаємодіють та перебуває під впливом дії низки чинників зовнішнього i внутрішнього середовища. Тому ефективне його функціонування в цілому, а також кожного процесу, зокрема технологічного оновлення виробництва, забезпечення синергічного ефекту від його здійснення, досягається завдяки належному управлінню діяльністю підприємства та інноваційним процесом у тому числі.

O.I. Вікарчук $[4$, с. 1-6], С.В. Князь та Н.М. Комарницька $[5$, с. 121] розглядають систему управління інноваційною діяльністю як одну із складових загальної системи управління (менеджменту) підприємства.

Ю.М. Уткіна, А.В. Вісільова вважають інноваційний менеджмент самостійною галуззю 
управлінської науки та професіональної діяльності, спрямований на забезпечення інноваційного розвитку підприємства [6, с. 299300], виокремлюючи при цьому виробничотехнологічний, збутовий та управлінський аспекти його визначення.

Влучним $є$ визначення інноваційного менеджменту, запропоноване О.А. Колесниковим: “комплексне системне використання знань, способів, методів, прийомів і форм управління діяльністю, метою якої є здійснення і впровадження нововведень для одержання конкурентних переваг на ринку" [7, с. 53].

Вищезазначені дослідники однозначні в тому, що управління інноваційною діяльністю $є$ важливою складовою управління підприємством i спрямоване на його розвиток та підвищення ефективності функціонування.

Управління технологічним оновленням виробництва як складова управління інноваційною діяльністю на підприємстві задіює операційний, інноваційний, фінансовий менеджмент, менеджмент персоналу та управління маркетингом.

Важливими аспектами, які вважаємо за доцільне розглянути у процесі дослідження менеджменту інноваційного розвитку та технологічного оновлення виробництва у сільськогосподарських підприємствах є:

-завдання інноваційного менеджменту щодо технологічного оновлення виробництва;

-функції інноваційного менеджменту у процесі технологічного оновлення виробництва.

На основі опрацювання економічних джерел $[1$, c. $260-266 ; 2$, с. $620-625 ; 3$, с. $19-30 ; 4$, с. 1 $6 ; 5$, с. $120-123 ; 6$, с. $299-300 ; 7$, с. $52-55$; 8, с. $193-$ 195] визначено основні завдання інноваційного менеджменту щодо технологічного оновлення виробництва сільськогосподарських підприємств, зокрема:

1. Аналіз попиту i пропозиції на ринку відповідно до сучасних умов господарювання.

2. Вибір цільового ринкового сегмента.

3. Вивчення новітніх досягнень науки, техніки, технологій.

4. Прогнозування змін ситуації на ринку у майбутньому.

5. Формулювання основних напрямів стратегії інноваційної діяльності.

6. Визначення мети, цілей та завдань технологічного оновлення виробництва у діяльності підприємства

7. Вибір оптимальної стратегіï на основі проведених розрахунків та аналізу.

8. Реалізація обраної стратегії щодо технологічного оновлення виробництва шляхом організації та мобілізації необхідних ресурсів.
9. Розробка тактичних напрямів щодо технологічного оновлення виробництва.

10. Оцінка ефективності прийнятих стратегічних і тактичних рішень.

11. Керівництво і контроль впродовж усього технологічного процесу.

12. Аналіз зовнішніх і внутрішніх чинників впливу на технологічне оновлення виробництва.

O.І. Вікарчук до функцій інноваційного менеджменту відносить: управління процесами створення нових знань; управління творчим потенціалом тих, хто створює нові знання; управління освоєнням нововведень; управління соціальними та психологічними аспектами нововведень [4, с. 2]. Інші автори [5, с. 122] до функцій інноваційного менеджменту зараховують планування, організування, стимулювання інноваційної діяльності, реалізацію інноваційних проектів.

Функціями інноваційного менеджменту у процесі технологічного оновлення виробництва вважаємо: планування, організацію, мотивацію, керівництво, контроль, розвиток.

Планування. Планування - це функція управління, результатом якої є складання планів. Основою ефективного планування $€$ аналіз внутрішніх можливостей підприємства та зовнішніх факторів впливу мікро- і макрорівня, зокрема ринкового середовища (аналіз споживачів, конкурентів, постачальників; становища підприємства на ринку). План технологічного оновлення виробництва повинен охоплювати стан та прогнозування тенденцій на ринку досліджуваної продукції; етапи його здійснення, очікувані результати, необхідні ресурси, тривалість реалізації, виконавців, аналіз впливу факторів, оцінку ризиків, прогнозування подальшого розвитку.

Планування чинить позитивний вплив на діяльність підприємства, в тому числі економічну ефективність. Планування технологічного оновлення виробництва має стати складовою корпоративного бізнес-плану.

Мотивація. Як і будь-яка інша діяльність на підприємстві, технологічне оновлення виробництва потребує мотивації його здійснення 3 урахуванням матеріальної та моральної іiі складових. Основним мотивом діяльності для підприємця $\epsilon$ досягнення економічної ефективності у вигляді прибутку та рентабельної діяльності, формування позитивної репутації серед клієнтів на основі забезпечення екологічної і соціальної ефективності продукції. Інноваційний шлях розвитку забезпечує дохідність підприємства на перспективу, тобто таке підприємство має більше шансів утримати домінуюче положення на ринку i виграти у 
конкурентній боротьбі. Для персоналу підприємства мотивацією $є$ можливість збільшення зарплати за рахунок зростання прибутку в результаті успішної діяльності підприємства на ринку. Моральна мотивація для працівників - праця на передовому підприємстві, яке постійно розвивається, має позитивний імідж, стабільна робота і заробітна плата 3 перспективою її зростання.

Організація передбачає здійснення заходів 3 метою створення належних умов для реалізації процесу технологічного оновлення виробництва, залучення та мобілізацію усіх необхідних ресурсів (сировинних, технологічних, технічних, людських, інформаційних, фінансових) у відповідний час, відповідному місці, відповідній кількості та належної якості. Тобто це, насамперед, організація маркетингових заходів 3 визначення ситуації на ринку, стану попиту та пропозиції; встановлення осіб, причетних до процесу управління та безпосереднього здійснення технологічного оновлення виробництва; укладання договорів 3 постачальниками та поставку продукції відповідної кількості та якості згідно технології; забезпечення технічних характеристик обладнання; своєчасна оплата необхідних заходів; налагодження взаємозв'язку між підрозділами, причетними до здійснення технологічного оновлення виробництва; чіткий розподіл та координація робіт.

Керівництво. Усі функції, покладені на менеджмент інноваційного розвитку підприємства, реалізуються завдяки персоналу i через персонал. Важлива роль належить менеджерамноваторам, адже, як за зазначає В.В. Зянько, "вкладення коштів у підготовку менеджерів у сфері інноваційної діяльності, $\epsilon$ однією 3 найефективніших форм інвестицій” [8, с. 193]. Важлива роль у формуванні менеджера-новатора належить вищим навчальним закладам, бізнесцентрам, бізнес-школам, діловим клубам, які здійснюють підготовку, перепідготовку та підвищення кваліфікації фахівців з управління.

Для реалізації інноваційного проекту доцільно сформувати робочу групу, яка буде складатися 3 фахівців інноваційної діяльності, виробництва, економістів, маркетологів. Керівництво групою повинен здійснювати інноваційний менеджер, який володіє інформацією про стан справ на ринку, ресурси всередині організації та знаннями про передові досягнення i розробки. Завдання інноваційного менеджера - забезпечити взаємозв'язок між усіма ланками технологічного процесу. Крім цього, необхідно також визначити працівників, які будуть здійснювати керівництво процесом безпосередньо на виробництві.

Контроль передбачає

оцінювання поставлених цілей $\mathrm{i}$ досягнених результатів технологічного оновлення виробництва. Оцінювання необхідне протягом всього процесу управління, на кожному його етапі: на етапі планування - оцінювання реальності планів $\mathrm{i}$ можливості підприємства їх реалізувати; на завершальному етапі - порівняння планових, нормативних і фактичних результатів.

Розвиток технологічного оновлення виробництва покликаний забезпечити безперебійний процес його здійснення на підприємстві. Інноваційний розвиток передбачає безперервність інноваційного процесу, розробку і пропозицію нововведень; активну роботу над наступним нововведенням від моменту виведення останньої новації на ринок 3 урахуванням життєвого циклу продукції. Вважається, що на початковому етапі виведення виходу на ринок технологічно нового товару попит перевищує пропозицію, на середньому етапі попит практично дорівнює пропозиції, а на завершальному - попит менший пропозиції i підприємству доводиться шукати нові ринки збуту. Розвиток як функція управління повинен забезпечити здійснення заходів, спрямованих на проведення наступного технологічного оновлення виробництва.

Висновки та перспективи подальших досліджень. Таким чином, інноваційний менеджмент щодо технологічного оновлення виробництва сільськогосподарських підприємств $\epsilon$ невід'ємною складовою системи управління підприємством, охоплює завдання, принципи, умови, функції, стратегічні і тактичні дії з метою виведення процесу виробництва на якісно новий рівень, розвитку підприємства в цілому та забезпечення його конкурентних переваг на ринку. 3 метою ефективного здійснення технологічного оновлення виробництва необхідно управляти цим процесом, що передбачає планування, мотивацію, організацію, керівництво, контроль та розвиток.

Перспективи подальших досліджень у даному напрямку полягають в обгрунтуванні принципів, умов, стратегічних дій і тактичних заходів щодо організації менеджменту інноваційного розвитку та технологічного оновлення виробництва сільськогосподарських підприємств. 


\section{ПЕРЕЛІК ВИКОРИСТАНИХ ДЖЕРЕЛ}

1. Волков О.І. Економіка й організація інноваційної діяльності: підруч. / О.І. Волков, М.П. Денисенко, А.П. Гречан та ін. - К.: ВД “Професіонал”, 2004. - 960 с.

2. Герасимчук В.Г. Економіка та організація виробництва: підруч. / В.Г. Герасимчук, А.Е. Розенплентер. К.: Знання, 2007. -678 с.

3. Ілляшенко С.М. Менеджмент та маркетинг інновацій: монографія / С.М. Ілляшенко. - Суми: ВТД "Університетська книга", 2004. - 616 с.

4. Вікарчук О.I. Інноваційний менеджмент в Україні як складова загальної системи управління підприємством / О.I. Вікарчук. - С. 1-6. [Електронний ресурс]. - Режим доступу: http://eprints.zu.edu.ua/7746/1/statya_Vikarchuk\%20\%281\%29.pdf. 21.02.2018

5. Князь С.В. Місце та роль інноваційного менеджменту в системі управління підприємством / С.В. Князь, Н.М. Комарницька // Вісник соціально-економічних досліджень. - 2014. - Випуск 3 (54). - С. 120-123.

6. Уткіна Ю.М. Інноваційний менеджмент на підприємствах / Ю.М. Уткіна, А.В. Вісільова // Вісник економіки транспорту і промисловості. - 2014. - № 46. - С. 298-302.

7. Колесников О.А. Інноваційний менеджмент підприємств як об’єктивна необхідність в умовах ринку / О.А. Колесников. - С. 52-55. [Електронний ресурс]. - Режим доступу: http://dspace.nbuv.gov.ua/bitstream/handle/123456789/35881/56-Kolesnikov.pdf?sequence=1. 21.02.2018

8. Зянько В. В. Інноваційне підприємництво в Україні: проблеми становлення і розвитку: монографія / В. В. Зянько. - Вінниця: УНІВЕРСУМ-Вінниця, 2005. - 263 с.

\section{REFERENCES}

1. Volkov, O.I., Denysenko, M.P. \& Hrechan, A.P. (2004). Ekonomika y orhanizatsiia innovatsiinoi diialnosti: pidruchnyk [Economics and organization of innovation activity].- Kyiv : Profesional [in Ukrainian].

2. Herasymchuk, V.H. \& Rozenplenter, A.E. (2007). Ekonomika ta orhanizatsiia vyrobnytstva: pidruchnyk [Economics and organization of production]. - Kyiv : Znannia [in Ukrainian].

3. Illiashenko, S.M. (2004) Menedzhment ta marketynh innovatsii [Management and marketing of innovations].Sumy :Universytetska knyha [in Ukrainian].

4. Vikarchuk, O.I. Innovatsiinyi menedzhment $\mathrm{v}$ Ukraini yak skladova zahalnoi systemy upravlinnia pidpryiemstvom [Innovative management in Ukraine as a component of the overall enterprise management system]. Retrieved from: http://eprints.zu.edu.ua/7746/1/statya_Vikarchuk\%20\%281\%29.pdf [in Ukrainian].

5. Kniaz, S.V. \& Komarnytska, N.M. (2014). Mistse ta rol innovatsiinoho menedzhmentu v systemi upravlinnia pidpryiemstvom [The place and role of innovation management in the enterprise management system] Visnyk sotsialnoekonomichnykh doslidzhen, 3 (54), 120 - 123 [in Ukrainian].

6. Utkina, Yu.M. \& Visilova, A.V. (2014). Innovatsiinyi menedzhment na pidpryiemstvakh [Innovative management at enterprises] Visnyk ekonomiky transportu i promyslovosti, 46, 298-302 [in Ukrainian].

7. Kolesnykov, O.A. Innovatsinyi menedzhment pidpryiemstv yak obiektyvna neobkhidnist $\mathrm{v}$ umovakh rynku [Innovative management of enterprises as an objective necessity in the market conditions]. Retrieved from: http://dspace.nbuv.gov.ua/bitstream/handle/123456789/35881/56-Kolesnikov.pdf?sequence=1 [in Ukrainian].

8. Zianko, V. V. (2005) Innovatsiine pidpryiemnytstvo v Ukraini: problemy stanovlennia i rozvytku [Innovative entrepreneurship in Ukraine: problems of formation and development]. - Vinnytsia: UNIVERSUM [in Ukrainian].

Одержано15.03.2018 p. 